\title{
Osteosynthese van een mid-diafysaire femurfractuur met behulp van type I "tie-in-fixator" bij een kookaburra (Dacelo novaeguineae)
}

\author{
Osteosynthesis of a mid-diaphysis femoral fracture \\ by using a type I tie-in fixator in a kookaburra (Dacelo novaeguineae)
}

\author{
${ }^{1}$ L. Geerinckx, ${ }^{1}$ T. Verbeek, ${ }^{2}$ T. Hellebuyck \\ ${ }^{1}$ Dierenartsencentrum Trigenio, Dorsel 38, B-2560 Nijlen, België \\ ${ }^{2}$ Vakgroep Pathologie, Bacteriologie en Pluimveeziekten, Faculteit Diergeneeskunde, Universiteit Gent, \\ Salisburylaan 133, B-9820 Merelbeke, België
}

Lise.Geerinckx@gmail.com

AMENVATTING

In deze casus wordt de succesvolle behandeling beschreven van een traumatische mid-diafysaire femurfractuur met behulp van een type I "tie-in-fixator" bij een kookaburra.

Een vijf maanden oude, in gevangenschap gehouden kookaburra (Dacelo novaeguineae) werd aangeboden met trauma ten gevolge van interspecies-agressie. Op basis van klinisch en radiografisch onderzoek werd de aanwezigheid van een gesloten, multipele, dwarse tot spiraalvormige, mid-diafysaire femurfractuur vastgesteld. Na reductie van de fractuur werd stabilisatie bekomen door het toepassen van een type I tie-in-fixator bestaande uit een combinatie van een intramedullaire (IM) pin en een externe skeletale fixator. Postoperatieve radiografische opnamen bevestigden een optimale reductie van de fractuur en een correcte plaatsing van het osteosynthesemateriaal. Postoperatief trad er een vlotte recovery op en werden er onmiddellijk een goede steunname en normale belasting van de aangetaste poot waargenomen. Hoewel de externe fixatie een week later door de vogel verwijderd werd, bleek er nog steeds goede stabilisatie aanwezig te zijn en bleef de functionaliteit van de aangetaste poot behouden. Twee weken postoperatief bevestigden controleradiografieën fractuurheling die gekarakteriseerd werd door lichte callusvorming en een startende overbrugging van de cortices. Op basis van de klinische en radiografische bevindingen werd besloten om de IM-pin op dat ogenblik te verwijderen. Tijdens een opvolgingsperiode van drie maanden vertoonde de kookaburra volledig herstel.

\section{ABSTRACT}

In this case report, the successful management of a traumatic fracture of the femur in a kookaburra using a type I tie-in-fixator (TIF) is described.

A domesticated, five-month-old kookaburra (Dacelo novaeguineae) suffered trauma due to interspecies aggression. Clinical and radiographic examination showed a closed, multiple transverse, spiral femoral fracture, located in the mid-diaphysis. Reduction of the fracture was managed using a type I TIF, combining an intra-medullar (IM) pin in combination with an external skeletal fixator. Postoperative radiographs confirmed an optimal reduction of the fracture and a correct placement of the type I TIF. Recovery was uneventful and correct positioning and normal functioning of the leg were observed immediately following surgery. One week postoperatively, the bird removed the external fixation but this did not interfere with the acquired stability and positioning of the affected leg. Two weeks after the surgery, radiographs confirmed a good healing of the fracture as callus development and bridging of the cortices were present. Based on the clinical and radiographic findings, it was decided to remove the IM pin. During a three-month follow-up period, the kookaburra showed full recovery. 


\section{INLEIDING}

De gewone kookaburra (Dacelo novaeguineae) is de grootste ijsvogelsoort en behoort tot de orde van de Coraciiformes of scharrelaarvogels. Volwassen vogels kunnen een gewicht tot een halve kilogram en een lengte van 30 tot $40 \mathrm{~cm}$ bereiken. De soort wordt wereldwijd succesvol in gevangenschap gehouden en gekweekt.

Het optreden van fracturen ten gevolge van trauma komt zowel bij in gevangenschap gehouden als wildlevende vogels frequent voor. Onafhankelijk van de uitlokkende oorzaak en in combinatie met de typische fysiologische en anatomische eigenschappen van het musculoskeletale systeem van vogels wordt er dikwijls een karakteristieke klinische presentatie waargenomen (Wood, 1941; Stout, 2016). Dikwijls zijn fracturen bij vogels namelijk gefragmenteerde, complexe en open fracturen.

In vergelijking met zoogdieren zijn de beenderen van vogels immers licht, hebben een relatief dunne cortex, zijn verschillende botten luchthoudend en zijn er weinig beschermende weke delen rondom het distale deel van de ledematen aanwezig. Deze bijzondere skeletale eigenschappen die vogels enerzijds uitstekend aangepast hebben aan het vliegen, predisponeren hen anderzijds voor het relatief snel optreden van fracturen en fissuren ten gevolge van trauma (Bennett en Kuzma, 1992; Martin en Ritchie, 1994; Redig en Ponder, 2016).

In deze casus worden de diagnostische benadering, succesvolle behandeling en postoperatieve opvolging beschreven van een kookaburra met een traumatische, mid-diafysaire femurfractuur. Daarnaast worden de bevindingen vergeleken met de huidig beschikbare literatuur omtrent fractuurbehandeling bij vogels.

\section{CASUÏSTIEK}

Een vijf maanden oude kookaburra (Dacelo novaeguineae) met een gewicht van $250 \mathrm{~g}$ werd aangeboden met trauma ten gevolge van interspeciesagressie. Onmiddellijk na het optreden van het trauma werd marbofloxacine $(10 \mathrm{mg} / \mathrm{kg}$ lichaamsgewicht (LG), per oraal, Marbocyl 5mg, Vétoquinol B.V., 's-Hertogenbosch, Nederland) en meloxicam $(0,2 \mathrm{mg} /$ $\mathrm{kg}$ LG, per oraal, Metacam $0,5 \mathrm{mg} / \mathrm{mL}$, Boehringer IngelheimVetmedica $\mathrm{GmbH}$, Ingelheim, Duitsland) door de eigenaar toegediend. Tijdens het klinisch onderzoek werd er exorotatie van de rechterpoot vastgesteld met afwezigheid van steunname. Er was een oppervlakkige huidwonde zichtbaar ter hoogte van de rechterbil. Bij palpatie van de femur werd een fractuur gevoeld ter hoogte van de mid-diafyse en was er crepitatie van het distale deel van het lidmaat aanwezig. Er werden geen andere klinische afwijkingen vastgesteld en de vogel vertoonde een alerte houding en goede algemene toestand.

Anesthesie werd geïnduceerd via een masker met $4 \%$ isofluraan (Isoflo, Abbott Laboratories Ltd., Berkshire, het Verenigd Koninkrijk) in 1,5 $\mathrm{L} \mathrm{O}_{2} / \mathrm{min}$ en onderhoud van de anesthesie werd bekomen door middel van de toediening van $2 \%$ isofluraan in $1,5 \mathrm{~L} \mathrm{O}_{2} / \mathrm{min}$. Er werd een ventrodorsale, radiografische overzichtsopname en een links-rechts laterale radiografie geno-
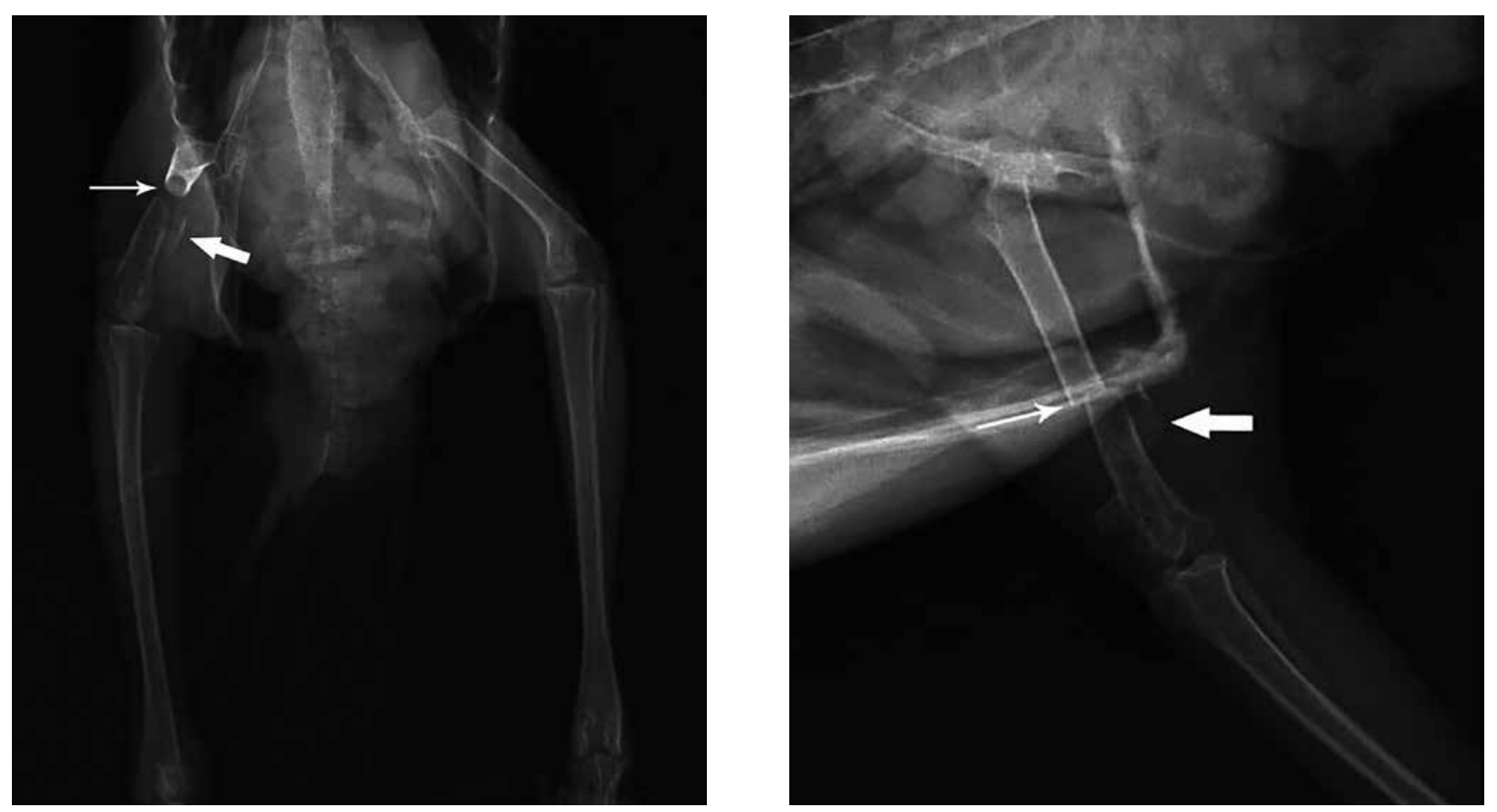

Figuur 1 en 2. Preoperatieve ventrodorsale en laterale radiografie van de rechterfemur bij een kookaburra. De multipele dwarse tot schuine fractuur is duidelijk zichtbaar ter hoogte van de proximale tot mid-diafysaire femur (dunne pijl). Een verplaatst los botfragment is aanwezig caudomediaal van de fractuurlijn (dikke pijl). 

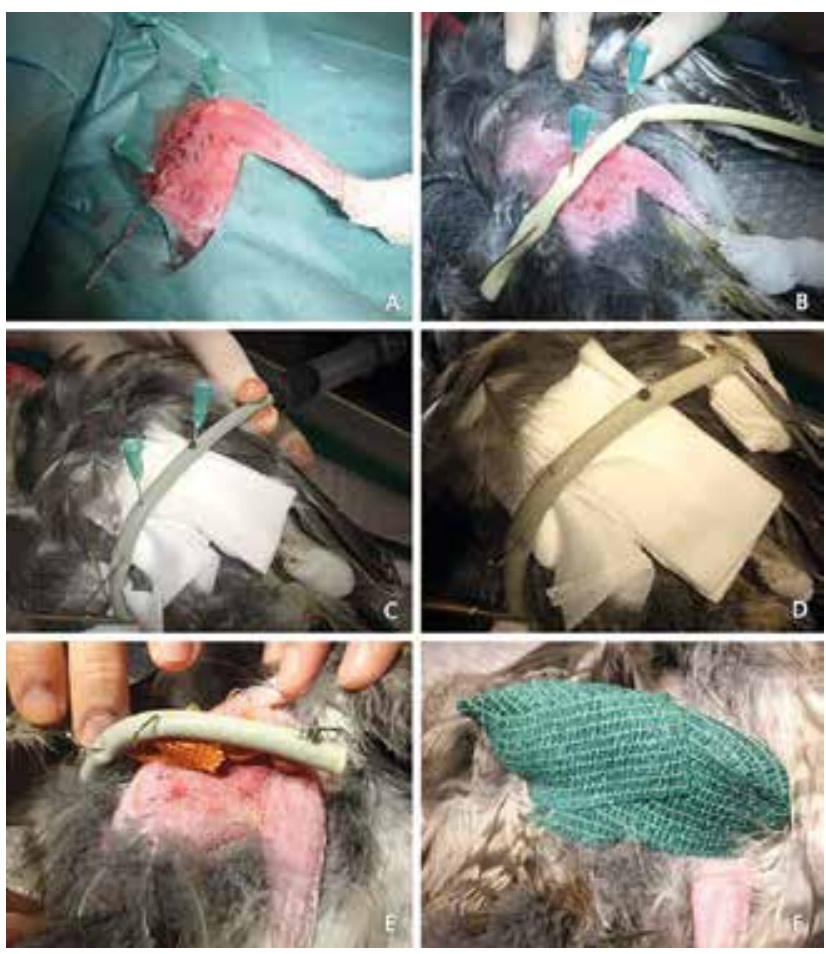

Figuur 3. Osteosynthese van een mid-diafysaire femurfractuur bij een kookaburra met een type I TIF. Plaatsing van de intramedullaire pin (A), plaatsing van de externe fixator die bestaat uit twee hypodermische 21Gnaalden en een penrosedrain (B) en opvulling van de penrosedrain met technovit voor extra stabilisatie (C). De conussen van de naalden worden verwijderd en de uiteinden worden parallel gebogen in de lengteas van de femur (D), een iso-Betadine compres wordt aangebracht tussen de externe fixatie en het been van de vogel (E). De externe fixatie wordt afgeschermd met behulp van een verband $(F)$.

men van de heup, femur en tibiotarsus (Figuur 1 en 2). Radiografisch werden een erge wekedelenzwelling ter hoogte van de proximale femur en een multipele fractuur ter hoogte van de mid-diafyse van de rechterfemur vastgesteld. De proximale fractuurlijn vertoonde een dwars verloop terwijl de distale fractuurlijn spiraalvormig verliep. Het proximale fragment van de femur was $20 \mathrm{~mm}$ lang, terwijl het distale fragment $15 \mathrm{~mm}$ mat. De diameter van de mergholte van de femur bedroeg ongeveer $3 \mathrm{~mm}$. Een los botfragment van $5 \mathrm{~mm}$ was aanwezig tussen beide fractuurlijnen dat verplaatst was naar caudomediaal. Ter hoogte van de rechterheup, rechtertibiotarsus en linkerpoot werden geen fracturen waargenomen.

Op basis van de radiografische beoordeling werd de diagnose gesteld van een gesloten, multipele, mid-diafysaire dwarse tot spiraalvormige femurfractuur en werden een operatieve reductie/allignatie en stabilisatie gekozen als meest gepaste therapeutische benadering. Operatief werd hetzelfde anesthesieprotocol aangewend als hoger beschreven. Er werd geen bijkomende analgesie gegeven aan de vogel na de eerdere meloxicamtoediening. De femur werd benaderd via een craniolaterale huidincisie van de trochanter major van de femur tot de laterale femurcondyl. De huid en de fascie werden ingesneden waarna de musculus iliotibialis lateralis, m. femorotibialis externus en $\mathrm{m}$. iliofibularis verplaatst werden om de femur en de fractuurhaard te visualiseren. Een intramedullaire (IM) pin (negatief geschroefde kirschnernagel, $1 \mathrm{~mm}$ diameter, Eickemeyer, Cumemborg, Nederland) werd via de fractuursite retrograad naar de trochanter major toe ingebracht. Er kon vervolgens een uitstekende reductie van de fractuur bekomen worden, waarbij het losse fragment op zijn correcte anatomische positie werd geplaatst zonder extra gefixeerd te worden. De IM-pin werd vervolgens normograad doorheen het distale fragment van de femur opgeschoven tot er weerstand voelbaar was (Figuur 3A). De IM-pin werd ingekort om trauma te vermijden. De huid werd samen met de subcutis gehecht met behulp van een doorlopende hechting met Polysorb 4/0 (Polysorb, Covidien, Mechelen, België). Twee 21G-naalden (Terumo Agani Needle 0,8x16mm, Terumo Europe NV, Leuven, België) werden gebruikt als externe skeletale fixatie (ESF). Eén naald werd in het proximale fragment geplaatst ter hoogte van de trochanter major en één naald in het distale fragment ter hoogte van de femurcondyl. De naalden werden beide van lateraal naar mediaal ingebracht. Postoperatieve radiografische beoordeling toonde een reductie van de fractuur en een correcte plaatsing van de IM-pin en externe fixator aan (Figuur 4). Vervolgens werden de twee externe 21G-naalden verbonden met elkaar door middel van een "penrosedrain" met een diameter van $6 \mathrm{~mm}$ (Penrose Drain Steriel, $6 \mathrm{~mm}$ x $45 \mathrm{~cm}$, Covidien, Mechelen, België) (Figuur 3B). Na het aanbrengen van compressen tussen de huid en de drain om contact met de huid te vermijden, werd het buisje gevuld met Technovit (Elektron Microscopy Sciences, Hatfield, het Verenigd Koninkrijk) (Figuur 3C). Op deze manier werd een externe type I tie-in-fixator (TIF) verwezenlijkt. Na uitharding werden de gekleurde naaldconussen verwijderd en de resterende delen van de naalden geplooid zodat deze parallel verliepen met de lengteas van de femur (Figuur 3D). Tussen de poot en de externe fixatie werd een zo beperkt mogelijke afstand gelaten zodat het geheel stabieler was. Hierbij werd rekening gehouden met een eventuele postoperatieve wekedelenzwelling. Tussen de externe fixator en de poot werd een iso-Betadine-compres (iso-Betadine, Meda Pharma, Brussel, België) aangebracht om irritatie en beschadiging van de poot te vermijden (Figuur $3 \mathrm{E})$. Tenslotte werden een verband met fixatiewindel (Elastomull, BSN Medical, Leuven, België) en cohesieve bandage (Wrapz, Millpledge Veterinary, Wingene, België) aangebracht rondom de externe fixator om te vermijden dat de vogel deze zou mutileren of vroegtijdig zou verwijderen (Figuur 3F). Er trad een vlotte recovery op na de anesthesie en de vogel vertoonde onmiddellijk volledige steunname ter hoogte van de rechterpoot. De vogel kreeg postoperatief een eenmalige intramusculaire injectie met meloxicam $(0,2$ $\mathrm{mg} / \mathrm{kg} \mathrm{LG}$ ) en marbofloxacine (10 mg/kg LG, Baytril, 


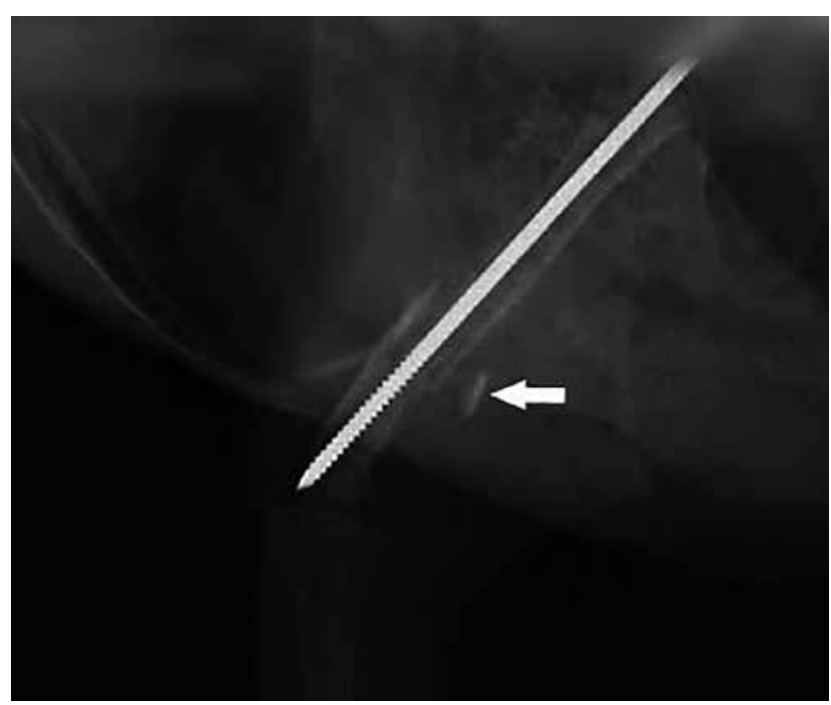

Figuur 4. Intraoperatieve radiografie om de plaatsing van de interne en externe skeletale fixatie te controleren bij osteosynthese van een femurfractuur door middel van een type I TIF bij een kookaburra. Het osteosynthesemateriaal is optimaal geplaatst en de femurfractuur werd mooi gereduceerd. Het verplaatste fragment kon niet geïncorporeerd worden in het TIF-materiaal (dikke pijl).

Bayer B.V., Mijdrecht, Nederland) toegediend. Marbofloxacine $(10 \mathrm{mg} / \mathrm{kg} \mathrm{LG}$, Marbocyl $5 \mathrm{mg} 1$ tablet $)$ en meloxicam $(0,2 \mathrm{mg} / \mathrm{kg} \mathrm{LG}$, Metacam $0,5 \mathrm{mg} / \mathrm{mL})$ werden eenmaal daags via perorale toediening tot de tiende dag postoperatief gegeven. Er werd geadviseerd om de vogel in een kleine kooi te plaatsen om hem rustig te houden en tien dagen later werd er een controlebezoek gepland. Een week postoperatief had de kookaburra echter spontaan het verband en de externe fixator, zowel de naalden als de verharde drain, verwijderd, waardoor de vogel reeds op dat ogenblik aangeboden werd. Aangezien er nog steeds een normale steunname was en er geen abnormaliteiten aan het osteosynthesemateriaal werden opgemerkt, werd er beslist de ESF niet te vervangen.

Twee weken postoperatief werd er een nieuw controlebezoek gepland. De aangetaste poot bleek nog steeds correct gepositioneerd en volledig belast te worden en bovendien werd de aanwezigheid van callusweefsel ter hoogte van de fractuurhaard via palpatie vastgesteld tijdens het klinisch onderzoek. De vogel werd opnieuw onder anesthesie gebracht via hetzelfde protocol als hierboven beschreven om radiografische opnamen te maken (Figuur 5). Deze radiografische controle toonde aan dat er callusvorming aanwezig was tussen de fractuurlijnen, de positie van de IMpin ongewijzigd was en er geen lucentie zichtbaar was ter hoogte van de intredeplaats van de IM-pin in de proximale femur. Zowel het middelste femurfragment als het distale fragment bleek licht naar craniaal verplaatst te zijn. Dit veroorzaakte geen instabiliteit noch interferentie met de fractuurheling. Na het zien van de gunstige radiografische evolutie werd beslist om de

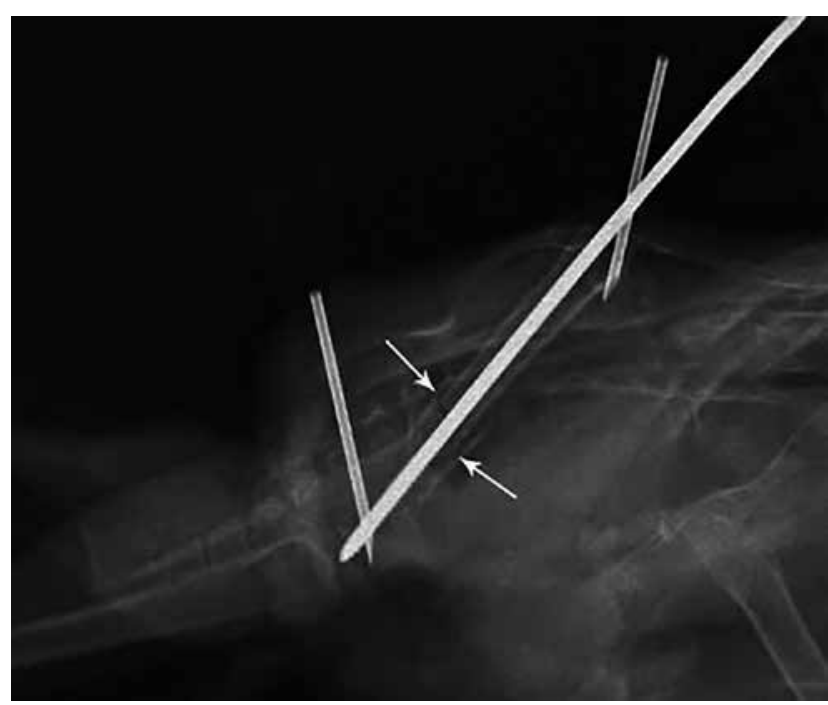

Figuur 5. Postoperatieve controle twee weken na de plaatsing van de type I TIF in de rechterfemur bij een kookaburra. Er is geen lucentie rondom het osteosynthesemateriaal zichtbaar en callusvorming is aanwezig ter hoogte van de vroegere fractuurlijn (dunne pijlen).

IM-pin te verwijderen. De vogel deed het meteen na het verwijderen van de pin en gedurende een followup-periode van drie maanden uitstekend.

\section{DISCUSSIE}

Fracturen van traumatische oorsprong komen veel voor in de vogelgeneeskunde en er dient steeds een volledig klinisch onderzoek uitgevoerd te worden bij deze patiënten (Bennet en Kuzma, 1992; Helmer en Redig, 2005; Stout, 2016). Dikwijls is er zowel preoperatieve stabilisatie van de patiënt noodzakelijk met onder andere analgetica, antibiotica, vloeistoftherapie en dwangvoederen, als primaire stabilisatie van fracturen met behulp van verbanden of spalken (Martin en Ritchie, 1994). Wanneer de vogel gestabiliseerd is, kan gericht onderzoek worden uitgevoerd om de uitgebreidheid van het trauma correct in te schatten. Radiografisch onderzoek laat toe om de aanwezigheid van fracturen of inwendig trauma te evalueren. Zelfs wanneer een fractuur reeds vermoed wordt op basis van het klinisch onderzoek blijft het belangrijk om een radiografisch onderzoek uit te voeren. De karakteristieken van de fractuur bepalen immers de voorkeursbehandeling. Radiografie wordt niet alleen gebruikt bij het aanbieden van de vogel na trauma, maar speelt ook een belangrijke rol in de postoperatieve opvolging van fracturen (Samour en Naldo, 2007).

Dikwijls zijn fracturen bij vogels multipele complexe splinterfracturen. Door deze splintervorming zijn fracturen bij vogels vaak open, wat een gereserveerde prognose met zich meebrengt door een verhoogde kans op infectie. Alhoewel femurfracturen vaak vastgesteld worden bij vogels, zijn ze dikwijls minder complex dan fracturen van andere lange been- 
deren door de relatief goede bespiering. De femur bij vogels vertoont typisch dwarse diafysaire fracturen na trauma (Hatt, 2008), zoals dit ook bij de vogel uit deze casus het geval was. Dit type fractuur vergemakkelijkt de behandeling, aangezien splinterfracturen zeer moeilijk te herstellen zijn. De plaatsing van IMpinnen en externe fixatie zijn bij splinterfracturen immers zo goed als onmogelijk en dus geen optie.

De algemene principes van osteosynthese die bij zoogdieren gelden, kunnen eveneens toegepast worden bij vogels. Zo zijn de belangrijkste aspecten een stevige fixatie van de fragmenten, een goede appositie en alignatie van de beenderen en een aseptische chirurgische werkwijze (Westfall en Egger, 1979; Martin en Ritchie, 1994). Bij vogels is het uitermate belangrijk dat de lengte van de beenderen bilateraal gelijk blijft voor het behoud van hun evenwicht en hun vliegmechanisme (Westfall en Egger, 1979). Bijkomend doet een proportioneel verschil in lengte van de poten het gewicht van de vogel verschuiven naar een van beide poten met de ontwikkeling van pododermatitis ("bumble foot") of artritis tot gevolg (Martin en Ritchie, 1994).

Voor de behandeling van fracturen bij vogels zijn verschillende methoden mogelijk. Deze methoden worden opgedeeld in drie grote groepen: externe coaptatie, externe skeletale fixatie en interne fixatie. Combinaties zijn mogelijk.

Externe coaptatie omvat bandages en spalken. Deze methode geeft slechts geringe stabiliteit aan de fractuur en kan dus enkel toegepast worden wanneer er een minimale verplaatsing is van de fragmenten of tijdelijk in afwachting van externe en/of interne fixatie (Helmer en Redig, 2005). Bij femurfracturen is het verkrijgen van een goede stabilisatie door het toepassen van externe coaptatie bij vogels moeilijk te verwezenlijken, waardoor andere technieken de voorkeur krijgen. Deze technieken worden geregeld gebruikt bij kleinere vogelsoorten, omdat andere technieken hierbij veel moeilijker toepasbaar zijn door hun zwaardere gewicht en grotere afmetingen.

Externe skeletale fixatie (ESF) omvat osteosynthesetechnieken waarbij materiaal extern wordt aangebracht. ESF is bruikbaar bij kleine vogels (Westfall en Egger, 1979), maar wordt het beste vermeden omdat het te zwaar is voor deze lichtere vogelsoorten (Hatt et al., 2007). Als alternatief kan er bij kleine vogelsoorten gebruik gemaakt worden van spalken en bandages (zie supra). Kirschnerdraden of steinmannpinnen worden ingebracht in het bot en daarna met elkaar verbonden. Dit kan onder andere bekomen worden door middel van drains die gevuld worden met cement of polymethylmethacrylaat (PMMA). Op deze manier wordt een grotere stabiliteit verkregen dan met enkel externe coaptatie (Westfall en Egger, 1979). Naast een zeer goede stabiliteit zijn er nog enkele voordelen aan externe fixatie. Zo is externe fixatie zeer licht, goedkoop, relatief gemakkelijk te plaatsen en te verwijderen en wordt het meestal goed getolereerd door vogels, met uitzondering van Psitta- ciformes (Martin en Ritchie, 1994; Hatt et al., 2007). Wanneer deze vorm van osteosynthese op een correcte manier wordt geplaatst, worden alle mogelijke krachten op de fragmenten uitgeschakeld met een maximale stabiliteit tot gevolg. Minimaal moeten twee pinnen in elk fragment ingebracht worden, ideaal zelfs drie tot vier (Martin en Ritchie, 1994). Het aantal pinnen per fragment wordt echter beperkt door de afmeting van de fragmenten, zoals dit ook het geval was bij de besproken casus. Bij deze specifieke casus liet de presentatie van de femurfractuur het toe om met een beperkt aantal pinnen toch een uitstekende stabilisatie te bekomen. Dit werd bevestigd door middel van intraoperatieve evaluatie en postoperatieve radiografische controle. Belangrijk bij de plaatsing van een externe fixatie is dat de pinnen doorheen nieuw gemaakte incisies in de huid in het bot worden ingebracht ter preventie van het optreden van infectie. De hoek waarin de pinnen in het bot worden gestoken, heeft geen effect op het resultaat. Pinnen die loodrecht op het bot worden georiënteerd, geven dezelfde resultaten als diagonaal geplaatste pinnen (Hatt et al., 2007). De verbinding die gemaakt wordt tussen de verschillende pinnen wordt het beste zo dicht mogelijk bij de huid gemaakt, omdat dit een maximale stabiliteit geeft. Er moet uiteraard wel rekening gehouden worden met het eventueel postoperatief opzwellen van de weke delen.

Interne fixatie omvat verschillende mogelijkheden, zoals IM-pinnen en botplaatjes. Beide mogelijkheden worden meer gebruikt bij grotere vogelsoorten. Er zijn enkele factoren die het gebruik van botplaatjes moeilijker toepasbaar maken bij vogels dan bij zoogdieren aangezien de meeste diergeneeskundige platen ontwikkeld zijn voor fractuurbehandeling bij honden en katten. Deze platen zijn doorgaans te groot en te zwaar om succesvol aan te wenden tijdens fractuurbehandeling bij vogels en voornamelijk bij kleinere vogels is de chirurgische visualisatie van de breuk dikwijls onvoldoende om deze plaatjes te bevestigen (Westfall en Egger, 1979). IM-pinnen voldoen dikwijls niet als enige osteosynthesetechniek. Ze verhinderen immers niet alle rotatie- en buigkrachten, waardoor er nog steeds beweging mogelijk is. Een ander nadeel is dat er een grote kans is op migratie en rotatie van de pinnen omdat er een gebrek is aan dens bot in de metafyse van vogels. De aanwezigheid van de dunne metafysaire beentrabeculae beperkt de mogelijkheid tot vasthechting van de pinnen binnenin het bot (Redig en Ponder, 2016). Geschroefde IM-pinnen geven daardoor een betere vasthechting in het corticale bot en aldus betere resultaten (Hatt et al., 2007). Een IM-pin moet ongeveer $1 / 2$ tot $2 / 3$ van de mergholte van het bot vullen. Een bredere pin brengt de endostale bloedvoorziening immers in het gedrang met avasculaire necrose en pathologische fracturen tot gevolg (Martin en Ritchie, 1994).

Bij de patiënt uit deze casus werd gekozen voor een combinatie van externe en interne fixatie. Wanneer de externe fixator slechts aan één zijde van het 
bot wordt verbonden, spreekt men van een type I TIF. Deze techniek wordt in de literatuur omschreven als de optimale techniek ter stabilisatie van femurfracturen bij vogels (Orosz et al., 1992; Martin en Ritchie, 1994; Coles et al., 1997; Helmer en Redig, 2005; Hatt, 2008; Redig en Ponder, 2016).

Bij zoogdieren zijn de mechanismen van botheling uitvoeriger beschreven dan bij vogels (Martin en Ritchie, 1994). Bij het succesvol toepassen van osteosynthetische technieken bij zoogdieren ontwikkelt er zich steeds een uitgebreide periostale callus in tegenstelling tot bij vogels waar er zich doorgaans slechts een minimale callus vormt rondom de fractuursite. Dit doet vermoeden dat botheling bij vogels eerder verloopt volgens het primaire mechanisme (Westfall en Egger, 1979; Martin en Ritchie, 1994) in tegenstelling tot het secundaire mechanisme bij zoogdieren, zoals eerder aangehaald werd. Bij secundaire botheling wordt eerst een kraakbenige callus gevormd die later vervangen wordt door een benige callus. Primaire botheling vormt meteen een stevige verbinding tussen de botfragmenten zonder callusvorming. Dit verklaart waarom fracturen bij vogels sneller herstellen (Martin en Ritchie, 1994). Toch hangt de snelheid van herstel ook af van andere factoren, zoals onder andere hoe ver de fragmenten van elkaar verplaatst zijn, hoe goed de postoperatieve reductie en allignatie zijn, hoe stabiel de breuk is na reductie en hoe ernstig de doorbloeding beschadigd is. Zo herstellen dwarse fracturen sneller dan spiraalvormige of multipele breuken, omdat ze minder onderhevig zijn aan verschillende krachten. Ook het type bot speelt een belangrijke rol (Bennett en Kuzma, 1992; Martin en Ritchie, 1994). Zo zouden beenderen die luchtzakken bevatten, zoals de humerus en de femur, minder snel herstellen dan niet-luchthoudende beenderen. Ook extra-skeletale factoren spelen een rol op de helingstijd van een breuk. Zo worden er tijdens de ruiperiode bij vogels een transiënte, fysiologische vorm van milde osteoporose gezien en een gedaalde doorbloeding van beenderen, waardoor het helingsproces wordt afgeremd (Westfall en Egger, 1979; Portugal et al., 2011). De exacte helingstijd van beenderen bij vogels bedraagt gemiddeld een drietal weken. Radiografisch is bij goede stabilisatie een volledig herstel zichtbaar na zes weken (Bennett en Kuzma, 1992). Sequestratie van losse botfragmenten is bij vogels, in tegenstelling tot bij zoogdieren, een minder voorkomend probleem. Ervaringen van de auteurs tonen aan dat wanneer het losse botfragment intraoperatief als vitaal beoordeeld wordt en er postoperatief een goede reductie en alignatie worden verkregen, de kans op het optreden van deze complicatie klein is. Uiteraard is een goede klinische en radiografische opvolging steeds noodzakelijk wanneer er een risico op sequestratie aanwezig is.

Postoperatieve opvolging van fracturen is, net zoals bij andere diersoorten, zeer belangrijk bij vogels. Wanneer er complicaties optreden, moet zo snel mogelijk worden ingegrepen. Fractuurheling na gebruik van een IM-pin duurt vier tot zes weken zonder com- plicaties (Hatt, 2008). Coles (1997) vermeldde echter dat botheling bij kleine vogelsoorten radiografisch al kan vastgesteld worden na acht dagen terwijl volledig herstel optreedt na minstens 22 dagen. Postoperatieve radiografieën worden dan ook het beste genomen na twee en vier weken. De belangrijkste radiografische parameters die beoordeeld moeten worden tijdens de postoperatieve periode zijn de callusvorming en de plaatsing van het osteosynthesemateriaal (Martin en Ritchie, 1994). De botheling is zichtbaar als een lichte periostale reactie, sclerose en een verhoogde radiodensiteit in het mergkanaal van het bot (Samour en Naldo, 2007). Het osteosynthesemateriaal mag niet omgeven worden door osteolyse en er mag geen verplaatsing van het materiaal optreden. Dit wijst immers op een instabiel proces dat botheling verhindert. $\mathrm{Bij}$ de vogel uit deze casus werd beslist om reeds na elf dagen de IM-pin te verwijderen omdat er een goede callusvorming aanwezig was en omdat de vogel een zeer goede steunname vertoonde. Het ging hier om een zeer jonge vogel, wat een verklaring was voor de snelle heling van de femurfractuur.

Omtrent analgesie specifiek voor traumatische gevallen is er nog niet veel onderzoek gebeurd bij vogels. In het algemeen wordt meloxicam als een goede pijnstiller beschouwd voor de behandeling van orthopedische en abdominale pijn (Goessens et al., 2016), maar bij duiven zou het slechts efficiënt zijn in hogere doseringen vanaf $2 \mathrm{mg} / \mathrm{kg} \mathrm{LG}$ (Desmarchelier, 2012). Verder onderzoek naar de veiligheid van deze hogere dosering is noodzakelijk bij andere species, omdat alle farmacokinetische eigenschappen erg kunnen variëren tussen de verschillende vogelsoorten (Goessens et al., 2016). Andere NSAIDs die gebruikt worden bij vogels zijn onder andere carprofen, ketoprofen, piroxicam en celecoxib (Goessens et al., 2016), maar hierover is meer, voornamelijk praktisch gericht onderzoek nodig. Een studie van J. Paul-Murphy (2005) toonde aan dat buprenorphine aan een dosis van 0,1 $\mathrm{mg} / \mathrm{kg}$ IM geen analgetisch effect gaf bij een studie op grijzeroodstaartpapegaaien. Een concentratie van 1 $\mathrm{mg} / \mathrm{kg}$ IM butorphanol gaf wel analgesie bij kaketoes en grijzeroodstaartpapegaaien maar niet bij amazonepapegaaien (Paul-Murphy, 2005). Tramadol zou analgetisch werken bij muspapegaaien (Greenacre, 2008) maar verder onderzoek is noodzakelijk wat betreft het gebruik van dit opiaat als analgeticum bij fractuurbehandeling bij vogels. Fentanyl geeft slechts in zeer hoge doseringen een analgetisch effect bij kaketoes en wordt niet aangeraden door de excitatie die met de toediening gepaard kan gaan. In het algemeen zijn er op dit ogenblik relatief weinig studies beschikbaar die het gebruik en de klinische efficiëntie van analgetica documenteren bij vogels in het algemeen en het gebruik ervan bij vogels met trauma in het bijzonder.

De prognose van fracturen bij vogels is afhankelijk van het type fractuur en de gebruikte osteosynthesetechniek. Complexe en versplinterde fracturen verhinderen dikwijls het gebruik van externe en/of interne fixatie. Fracturen die dichtbij een gewricht 
gelegen zijn, hebben een grotere kans op ankylose. Open fracturen geven dan weer een grotere kans op de ontwikkeling van osteomyelitis en sepsis (Martin en Ritchie, 1994). De prognose voor femurfracturen is bij vogels over het algemeen goed (Orosz et al., 1992). De combinatie van externe met interne fixatie vormt meestal de voorkeursbehandeling.

\section{BESLUIT}

Fracturen ten gevolge van trauma komen veel voor bij vogels. Een optimale diagnostische benadering is noodzakelijk om de meest geschikte behandeling te selecteren en een goede uitkomst te garanderen. Verschillende technieken, zoals externe coaptatie, externe skeletale fixatie, interne fixatie of combinaties kunnen gebruikt worden om fracturen bij vogels te behandelen. TIF is een combinatie van externe skeletale fixatie en interne fixatie en wordt in de literatuur omschreven als een optimale osteosynthesetechniek bij vogels. Voornamelijk bij de behandeling van femurfracturen bij vogels wordt deze techniek vaak gebruikt, omdat externe coaptatie ter behandeling van dit type fracturen moeilijker uitvoerbaar is. Postoperatieve opvolging is zeer belangrijk in de evaluatie van fracturen bij vogels en wordt het beste bekomen met behulp van radiografische opnamen.

Voor de beschreven casus bleek het gebruik van een type I TIF eveneens de meest geschikte behandeling te zijn en leidde tot snel radiografisch en functioneel herstel. Ondanks het voortijdige verwijderen van ESF bleek voornamelijk de jonge leeftijd van de vogel een belangrijke factor te zijn met betrekking tot de snelle heling van de femurfractuur. De invloed van een verscheidenheid aan factoren, zoals de locatie en complexiteit van de fractuur, de vogelsoort en de leeftijd van de vogel, dient steeds in acht genomen te worden om een optimaal resultaat bij de behandeling van fracturen bij vogels te bereiken.

\section{LITERATUUR}

Bennett R.A., Kuzma A.B. (1992). Fracture management in birds. Journal of Zoo and Wildlife Medicine 23, 5-38.

Coles B.H. (1997). Surgery. In: Coles B.H. (editor). Essentials of Avian Medicine \& Surgery. Third edition, Blackwell Publishing, Oxford, 164-182.

Desmarchelier M., Troncy E., Fitzgerald G., Lair S. (2012). Analgesic effects of meloxicam administration on postoperative orthopedic pain in domestic pigeons (Columba livia). American Journal of Veterinary Research 73, 361367.

Goessens T., Antonissen G., Croubels S., De Backer P., Devreese M. (2016). Niet-steroïdale, anti-inflammatoire geneesmiddelen bij vogels: farmacokinetiek, farmacodynamiek en toxiciteit. Vlaams Diergeneeskundig Tijdschrift $85,55-62$.

Greenacre C. (2008). Pain management in avian patients. In: Kansas City Proceedings 2008.
Hatt J-M., Christen C., Sandmeier P. (2007). Clinical application of an external fixator in the repair of bone fractures in 28 birds. The Veterinary Record 160, 188-194.

Hatt J-M. (2008). Hard tissue surgery. In: Chitty J., Lierz M. (editors). BSAVA Manual of Raptors, Pigeons and Passerine Birds. British Small Animal Veterinary Association, Gloucester, 170.

Helmer P., Redig P.T. (2005). Surgical resolution of orthopedic disorders. In: Harrison G.J., Lightfoot T. (editors). Clinical Avian Medicine. Spix Publishing, Florida, 761773.

Martin H., Ritchie B.W. (1994). Orthopedic surgical techniques. In: Ritchie B.W., Harrison G.J., Harrison L.R., Wingers (editors). Avian Medicine: Principles and Application. Publishing, Florida, 1137-1169.

Orosz S.E., Ensley P.K., Haynes C.J. (1992). Anatomy of and surgical approaches to the leg: surgical approaches to the pelvic limb: femur. In: L. Mills (editor). Avian Surgical Anatomy: Thoracic and Pelvic Limbs. W.B. Saunders Company, Pennsylvania, 102-105.

Paul-Murphy J. (2005). Pain Management. In: Harrison G.J., Lightfoot T. (editors). Clinical Avian Medicine. Spix Publishing, Florida, 233-238.

Portugal S.J., Butler P.J., Green J.A., Cassey P. (2011). Indications of phenotypic plasticity in moulting birds: captive geese reveal adaptive changes in mineralisation of their long bones during wing moult. Journal of Ornithology 152, 1055-1061.

Redig P.T., Ponder J. (2016). Orthopedic surgery. In: Samour J. (editor). Avian Medicine. Third edition, Elsevier, Missouri, 333-340.

Samour J.H., Naldo J.L. (2007). Clinical and pathological conditions: trauma-related medical conditions. In: Samour J.H., Naldo J.L. (editors). Anatomical and Clinical Radiology of Birds of Prey. Saunders Elsevier, United Arab Emirates, 197-217.

Stout J.D. (2016). Common emergencies in pet birds. Veterinary Clinics of North America: Exotic Animal Practice 19, 325-668.

Westfall M.L., Egger E.L. (1979). The management of long bone fractures in birds. Iowa State University Veterinarian $41,81-86$.

Wood H.B. (1941). Fractures among birds. Bird-Banding $12,68-72$. 